\title{
Comparison of the Effects of Ornithine and Arginine on the Brain Protein Synthesis Rate in Young Rats
}

\author{
Shoko SuZumurA ${ }^{1}$, Kazuyo TujIOKA ${ }^{2}$, Takashi YAmADA ${ }^{3}$, \\ Hidehiko YoKOGOSHI ${ }^{3}$, Saori AKIDUKI ${ }^{4}$, Yukihiro HISHIDA ${ }^{4}$, \\ Kazumi TsuTSuI $^{1}$ and Kazutoshi HAYASE ${ }^{1, *}$ \\ ${ }^{1}$ Department of Home Economics, Aichi University of Education, Igaya-cho, \\ Kariya, Aichi 448-8542, Japan \\ ${ }^{2}$ Faculty of Early Childhood Care and Education, Ohkagakuen University, Toyoake, Aichi 470-1163, Japan \\ ${ }^{3}$ Department of Food and Nutritional Sciences, College of Bioscience and Biotechnology, \\ Chubu University, Matsumoto-cho, Kasugai, Aichi 487-8501, Japan \\ ${ }^{4}$ Healthcare Products Development Center, KYOWA HAKKO BIO CO., LTD., \\ Tsukuba, Ibaraki 305-0841, Japan \\ (Received January 23, 2015)
}

\begin{abstract}
Summary Brain protein synthesis and the plasma concentration of growth hormone (GH) are sensitive to dietary ornithine. The purpose of this study was to determine whether dietary arginine, the metabolite of ornithine, affects the brain protein synthesis, and to that end, the effects of arginine on brain protein synthesis were compared with that of ornithine treatment in young rats. Two experiments were done on five or three groups of young rats (5-wk-old) given $0 \%, 0.25 \%, 0.5 \%, 0.7 \%$ arginine or $0.7 \%$ ornithine- $\mathrm{HCl}$ added to a $20 \%$ casein diet for $1 \mathrm{~d}$ (only one $3 \mathrm{~h}$ period) (Experiment 1), or given a diet containing $0 \%$ or $0.7 \%$ ornithine- $\mathrm{HCl}$ or $0.7 \%$ arginine added to a $20 \%$ casein diet (Experiment 2 ). The concentrations of plasma growth hormone $(\mathrm{GH})$ and fractional rates of protein synthesis in the brains increased significantly with the $20 \%$ casein $+0.7 \%$ arginine diet and still more with the $20 \%$ casein $+0.7 \%$ ornithine diet compared with the $20 \%$ casein diet alone. In the cerebral cortex and cerebellum, the RNA activity [g protein synthesized/(g RNA d)] significantly correlated with the fractional rate of protein synthesis. The RNA concentration (mg RNA/g protein) was also related to the fractional rate of protein synthesis in these organs. The results suggest that the treatment with arginine is likely to increase the concentrations of $\mathrm{GH}$ and the rate of brain protein synthesis in rats, and that the effects of arginine on brain protein synthesis and GH concentration were lower than that of ornithine. The RNA activity is at least partly related to the fractional rate of brain protein synthesis.
\end{abstract}

Key Words ornithine, arginine, growth hormone, protein synthesis, brain

Concentrations of tissue proteins are affected by alterations in dietary proteins, age and hormonal factors. These changes in protein metabolism may be reflected in the rate of protein synthesis, especially in the liver, muscles and intestines (1-5). However, in comparison with studies of visceral organs, little documentation of brain protein synthesis is available. The evidence from several investigations indicates that protein synthesis in the brain also depends on dietary proteins and amino acids in young rats $(6,7)$.

In many investigations, growth hormone $(\mathrm{GH})$ deficiency has been shown to affect many functions related to the central nervous system in mammals $(8)$. GH is well known as the anabolic hormone in protein metabolism. Several investigators have demonstrated that the protein synthesis in visceral organs, skeletal muscle and

\footnotetext{
*To whom correspondence should be addressed.

E-mail: khayase@auecc.aichi-edu.ac.jp

Abbreviation: GH, growth hormone.
}

brains was increased by GH in rats $(9,10)$.

Ornithine is a kind of amino acid distributed in the liver of mammals and foods such as Corbicula (Asian clam). Ornithine is also metabolized to arginine by the hepatic urea cycle. The ornithine ingestion has been known to increase the plasma concentration of $\mathrm{GH}$ in humans and rats $(11,12)$. Recently, Tujioka et al. (13) reported that dietary ornithine increased the plasma concentration of $\mathrm{GH}$ and the rates of brain protein synthesis in sham-operated rats only, not in hypophysectomized rats, and that regulation in brain protein synthesis is mediated through changes in the body GH concentration when the dietary ornithine is manipulated. On the other hand, several investigators reported that treatment with arginine, a metabolite of ornithine, stimulated GH secretion in humans (14). However, the role of arginine in brain protein synthesis remains unknown in young rats. The purpose of our study was to determine whether dietary arginine affects brain protein synthesis, and whether higher rates of brain protein synthesis in 
Table 1. Effect of the addition of ornithine and arginine to a basal diet on the plasma concentration of growth hormone in rats. ${ }^{1}$

\begin{tabular}{lccc}
\hline Treatment with $\mathrm{Orn}^{2}$ and $\mathrm{Arg}^{3}$ & $\begin{array}{c}\text { Final body weight } \\
(\mathrm{g})\end{array}$ & $\begin{array}{c}\text { Food intake } \\
(\mathrm{g})\end{array}$ & $\begin{array}{c}\text { Plasma GH }^{4} \\
(\mu \mathrm{g} / \mathrm{L})\end{array}$ \\
\hline Control & $148.8 \pm 5.1$ & $10.9 \pm 0.4$ & $10.5 \pm 0.8^{\mathrm{d}}$ \\
$+0.7 \%$ Orn & $149.0 \pm 3.4$ & $10.6 \pm 0.4$ & $50.5 \pm 2.0^{\mathrm{a}}$ \\
$+0.25 \%$ Arg & $149.0 \pm 2.9$ & $10.9 \pm 0.3$ & $10.8 \pm 0.7^{\mathrm{d}}$ \\
$+0.5 \%$ Arg & $149.8 \pm 3.3$ & $10.9 \pm 0.4$ & $19.0 \pm 1.0^{\mathrm{c}}$ \\
$+0.7 \%$ Arg & $149.8 \pm 1.7$ & $10.8 \pm 0.4$ & $25.8 \pm 1.5^{\mathrm{b}}$ \\
\hline
\end{tabular}

\footnotetext{
${ }^{1}$ Values are means and SE, $n=6$. Means with different superscript letters are significantly different $(p<0.05)$.

${ }^{2}$ Ornithine.

${ }^{3}$ Arginine.

${ }^{4}$ Growth hormone.
}

rats treated with ornithine could be observed as compared with those of arginine-treated rats. In our previous report $(12,13)$, a positive correlation between the rate of protein synthesis and RNA activity was found in the brain when dietary ornithine was manipulated in young and aged rats. However, the reduction with age in protein synthesis in the brain was related to a fall in the RNA concentration (15). Three questions were considered in the present study: 1) whether the dietary addition of arginine might increase the plasma concentration of $\mathrm{GH}$ and brain protein synthesis in young rats, 2) whether in ornithine-treated rats, higher rates of brain protein synthesis might be found compared with those in arginine-treated rats, and 3) whether greater RNA concentration or RNA activity in young rats given arginine or ornithine resulted in a greater protein synthesis rate in the brain than those in rats fed the basal diet. Therefore, we examined the effects of arginine or ornithine treatment on the GH concentration in plasma and three indicators of protein synthesis in rat brains: its rate, RNA concentration and RNA activity in young rats. We have already reported that the plasma concentration depended on the level of dietary addition of ornithine, and the plasma concentration of $\mathrm{GH}$ was the highest in rats administrated $0.5 \%$ and $0.7 \%$ ornithine added to the $20 \%$ casein diet compared with control rats (12). Thus, in this study, we used five groups of young rats given $0 \%, 0.25 \%, 0.5 \%$, or $0.7 \%$ arginine or $0.7 \%$ ornithine- $\mathrm{HCl}$ added the $20 \%$ casein diet.

\section{Materials and Methods}

Chemicals. L-Tyrosine decarboxylase, L-leucyl-Lalanine and $\beta$-phenethylamine were purchased from Sigma Chemical (St. Louis, MO). L- $\left[2,4-{ }^{3} \mathrm{H}\right]$ Phenylalanine $(2.2 \mathrm{TBq} / \mathrm{mmol})$ was obtained from Moravek (Brea, $\mathrm{CA})$. L-Ornithine- $\mathrm{HCl}$ and arginine were obtained from KYOWA HAKKO BIO CO., LTD. (Tokyo, Japan). All other reagents were purchased from Wako Pure Chemical Industries, Ltd. (Osaka, Japan).

Animals and diet. Young male Wistar rats $(5 \mathrm{wk}$, Japan SLC, Inc., Hamamatsu, Japan) were housed at $24^{\circ} \mathrm{C}$ in a room with a 12 -h light-dark cycle. The rats were transferred to the basal diet or experimental diet
(13) after being fed a commercial non-purified diet (MF; Oriental Yeast Co., Ltd., Tokyo, Japan) for 2 d. All animals were individually housed and given free access to food and water. The approval of Aichi University of Education Animal Care and Use Committee was given for our animal experiments.

Experimental design. Experiment 1 was conducted on five groups of rats. In our previous experiment, the plasma concentration of GH rose very rapidly after ornithine treatment (12). Therefore, in the present study, the plasma concentration of $\mathrm{GH}$ was measured after only one 3-h feeding period of the test diet. After feeding on the $20 \%$ casein diet for $10 \mathrm{~d}$ (one 3 -h feeding period per day, from 9:00-12:00), the rats were assigned randomly to one of following five groups and given the experimental diets containing $0 \%, 0.25 \%, 0.5 \%$, or $0.7 \%$ arginine or $0.7 \%$ ornithine- $\mathrm{HCl}$ added to the $20 \%$ casein diet for $1 \mathrm{~d}$ (only one $3 \mathrm{~h}$ period). After the $3 \mathrm{~h}$ feeding period, the rats were decapitated. The concentration of plasma GH was measured by the method of EIA (SPI bio, Massy, Cedex, France). Experiment 2 was conducted on three groups of rats. All rats were fed the experimental diets for $10 \mathrm{~d}$ ad libitum. The experimental diets contained $0 \%, 0.7 \%$ ornithine $\mathrm{HCl}$ or $0.7 \%$ arginine added to the $20 \%$ casein diet (Table 1 ). The fractional rates of protein synthesis in the brain and liver were measured by the method of Garlick et al. (16). The rats were decapitated between 1000 and $1200 \mathrm{~h}$. Brain regions (17) and liver were quickly removed and frozen in liquid nitrogen. The concentrations of protein and RNA in the brain and liver were measured according to the methods of Lowry et al. with bovine serum albumin as a standard, and Fleck and Munro, respectively $(18,19)$.

Fractional rate of protein synthesis in tissues. Radioactive $\mathrm{L}-\left[2,4-{ }^{3} \mathrm{H}\right]$ phenylalanine was combined with unlabeled phenylalanine to yield a dose of $1.85 \mathrm{MBq}$ and a concentration of $150 \mu \mathrm{mol} / \mathrm{mL}$ saline. Rats were injected with the radioisotope via the tail vein at a dose of $1 \mathrm{~mL} / 100 \mathrm{~g}$ body weight. At $10 \mathrm{~min}$ after injection, rats were quickly decapitated. Specific radioactivities of $\left[{ }^{3} \mathrm{H}\right]$ phenylalanine in tissue samples were determined according to the method described in our previous report (20). In a preliminary experiment, we 
Table 2. Effect of the addition of ornithine and arginine to a basal diet on body weight gain, and relative weights in liver and brain regions. ${ }^{1}$

\begin{tabular}{|c|c|c|c|}
\hline & 20\% Casein & $\begin{array}{l}20 \% \text { Casein } \\
+0.7 \% \mathrm{Orn}^{2}\end{array}$ & $\begin{array}{l}20 \% \text { Casein } \\
+0.7 \% \mathrm{Arg}^{3}\end{array}$ \\
\hline Body weight gain $(\mathrm{g} / 10 \mathrm{~d})^{4}$ & $57.0 \pm 1.6$ & $54.6 \pm 2.9$ & $58.8 \pm 1.9$ \\
\hline Food intake (g/d) & $17.9 \pm 0.2$ & $17.8 \pm 0.2$ & $17.7 \pm 0.4$ \\
\hline \multicolumn{4}{|c|}{ Tissue weight (g/100 g body weight) } \\
\hline Liver & $4.39 \pm 0.08$ & $4.28 \pm 0.08$ & $4.22 \pm 0.05$ \\
\hline Cerebral cortex & $0.18 \pm 0.004$ & $0.17 \pm 0.004$ & $0.17 \pm 0.005$ \\
\hline Cerebellum & $0.14 \pm 0.004$ & $0.15 \pm 0.006$ & $0.14 \pm 0.006$ \\
\hline Hippocampus & $0.058 \pm 0.002$ & $0.058 \pm 0.001$ & $0.057 \pm 0.002$ \\
\hline
\end{tabular}

\footnotetext{
${ }^{1}$ Values are means and SE, $n=6$.

${ }^{2}$ Ornithine.

${ }^{3}$ Arginine.

${ }^{4}$ Initial body weight was $136-145 \mathrm{~g}$.
}

Table 3. Effect of the addition of ornithine and arginine to a basal diet on protein synthesis in liver and brain regions. ${ }^{1}$

\begin{tabular}{|c|c|c|c|}
\hline & $20 \%$ Casein & $\begin{array}{l}20 \% \text { Casein } \\
+0.7 \% \text { Orn }^{2}\end{array}$ & $\begin{array}{l}20 \% \text { Casein } \\
+0.7 \% \mathrm{Arg}^{3}\end{array}$ \\
\hline \multicolumn{4}{|c|}{ Protein synthesis (Ks) (\%/d) } \\
\hline Liver & $91.5 \pm 0.8^{c}$ & $112.6 \pm 0.9^{\mathrm{a}}$ & $101.5 \pm 1.0^{\mathrm{b}}$ \\
\hline Cerebral cortex & $19.7 \pm 0.2^{\mathrm{c}}$ & $24.8 \pm 0.1^{\mathrm{a}}$ & $21.9 \pm 0.3^{b}$ \\
\hline Cerebellum & $24.3 \pm 0.4^{\mathrm{c}}$ & $29.6 \pm 0.2^{\mathrm{a}}$ & $25.7 \pm 0.3^{b}$ \\
\hline Hippocampus ${ }^{4}$ & 24.0 & 28.3 & 25.2 \\
\hline \multicolumn{4}{|c|}{ RNA/protein (mg RNA/g protein) } \\
\hline Liver & $40.0 \pm 0.8$ & $40.6 \pm 0.4$ & $40.5 \pm 0.4$ \\
\hline Cerebral cortex & $15.0 \pm 0.2$ & $15.1 \pm 0.2$ & $15.1 \pm 0.1$ \\
\hline Cerebellum & $15.0 \pm 0.1$ & $14.9 \pm 0.2$ & $15.0 \pm 0.1$ \\
\hline Hippocampus ${ }^{4}$ & 15.4 & 15.5 & 15.3 \\
\hline \multicolumn{4}{|c|}{ RNA activity (g protein synthesized/g RNA $\cdot d$ ) } \\
\hline Liver & $22.9 \pm 0.4^{\mathrm{c}}$ & $27.8 \pm 0.5^{\mathrm{a}}$ & $25.1 \pm 0.3^{b}$ \\
\hline Cerebral cortex & $13.1 \pm 0.2^{\mathrm{c}}$ & $16.4 \pm 0.3^{\mathrm{a}}$ & $14.5 \pm 0.3^{\mathrm{b}}$ \\
\hline Cerebellum & $16.2 \pm 0.3^{\mathrm{c}}$ & $19.9 \pm 0.4^{\mathrm{a}}$ & $17.1 \pm 0.2^{\mathrm{b}}$ \\
\hline Hippocampus ${ }^{4}$ & 15.6 & 18.3 & 16.5 \\
\hline
\end{tabular}

determined whether the method of Garlick et al. (16) could be used to measure the rate of protein synthesis in the brain under this experimental condition. Specific radioactivities of free phenylalanine in the plasma, cerebral cortex and cerebellum in rats of the three groups were constant in each tissue (the data are not shown). Moreover, the values were also not significantly different among the plasma, cerebral cortex and cerebellum, indicating that the precursor pool of labeled phenylalanine was not different. In our previous report (7), the decrease in labeling of free phenylalanine at 3, 5 and $10 \mathrm{~min}$ in the brain was not significant after an injection of a large dose of $\left[{ }^{3} \mathrm{H}\right]$ phenylalanine. Therefore, the protein synthesis rates for brain regions were calculated for animals killed at a single time point of $10 \mathrm{~min}$ after intravenous administration of the radioisotope.
The fractional rates of protein synthesis (Ks) for brain regions were calculated from the specific radioactivity of phenylalanine in protein ( $\mathrm{Sb}$ ) at $10 \mathrm{~min}$ and the specific radioactivity of free phenylalanine in the tissue $(\mathrm{Sa})$ at $10 \mathrm{~min}$. The formula for calculating Ks has been given by Garlick et al. (16), i.e.

$\mathrm{Ks}(\% / \mathrm{d})=\mathrm{Sb} \times 100 / \mathrm{Sa} \times t$

where $t$ is the incorporation time in days.

The RNA activity was calculated by dividing the fractional rate of protein synthesis by the RNA/protein ratio. The absolute protein synthesis was calculated by multiplying the fractional rate of protein synthesis by the protein contents of tissues.

Statistical analysis. The means and SE values are reported. The Tukey-Kramer test was used to compared means after one way ANOVA (21). Linear regression 
analysis was used to assess the relationship between the rate of protein synthesis and RNA activity (21). Differences were considered significant at $p<0.05$. In the hippocampus, the rates of protein synthesis were determined from a pool of each region.

\section{Results and Discussion}

The amino acid supply has been shown to be important for the protein synthesis in the brain regions (9, 10). In our previous study, Tujioka et al. reported that the plasma concentration of $\mathrm{GH}$ and protein synthesis in the brains were increased in young rats treated with ornithine (12). Ornithine is a urea cycle intermediate and is metabolized to arginine by the urea cycle enzymes. Arginine has been known to stimulate GH secretion in humans (14). However, the role of arginine in brain protein synthesis remains unknown in young rats. Therefore, we determined whether not only dietary ornithine but also arginine increased the GH concentration in plasma and the protein synthesis in the brain regions. The plasma concentration of $\mathrm{GH}$ increased significantly with 0.5 and $0.7 \%$ arginine added to the $20 \%$ casein diet and still more with $20 \%$ casein $+0.7 \%$ ornithine compared with 20\% casein alone (Table 1). The treatment with arginine may have regulated plasma concentration of $\mathrm{GH}$, but the regulatory effect of arginine on GH status was lower than that of ornithine. The body weight gain and food intake were not significantly different among experimental groups. The weights of the brain regions and liver did not differ among experimental groups when expressed relative to body weight (Table 2).

In the brain regions such as the cerebral cortex and cerebellum, the fractional and absolute rates of protein synthesis rose significantly with casein, casein+arginine and casein + ornithine diets in that order (Table 3). In pooled samples of the hippocampus, this rate tended to be higher in the ornithine supplementation group than the control or arginine supplementation group (Table 3 ). The changes in brain protein synthesis depended on the supply of dietary ornithine and arginine, and were much higher in the ornithine-treated group than in the arginine-treated group. In previous studies, we reported that the treatment with ornithine increased the plasma concentration of $\mathrm{GH}$ and the rates of brain protein synthesis in sham-operated rats only, not in hypophysectomized rats (13). The regulation in brain protein synthesis is mediated through changes in the body GH concentration when dietary ornithine is manipulated. On the other hand, in the present study, the concentration of plasma $\mathrm{GH}$ also rose after arginine ingestion. However, several studies supported the possibility that arginine itself passed the blood-brain barrier (22). Therefore, the role of dietary arginine in brain protein synthesis in hypophysectomized rats is another question to consider in further study in order to investigate whether the changes in brain protein synthesis with arginine treatment are mediated through the concentration of GH.

The unanswered questions include whether ornithine itself or a metabolite of ornithine, arginine, mediates the effects of the ornithine on brain protein synthesis in young rats. Recently, Ohinata reported that the ornithine treatment increased the plasma concentration of GH with injection to the duodenum directly, not with intravenous injection (23). Ohinata also demonstrated that the ornithine treatment to the duodenum increased the mRNA level of ghrelin, a GH-releasing peptide, in the duodenum (23). Ghrelin in the gastrointestinal tract has been known to regulate $\mathrm{GH}$ release from the pituitary through the role of the afferent vegal nerve (24, 25). Ornithine may regulate $\mathrm{GH}$ secretion through the changes of ghrelin in the gastrointestinal tract. Arginine was metabolized from ornithine by the hepatic urea cycle enzymes alone, not in the gastrointestinal tract. Therefore, the higher protein synthesis in the brains and higher $\mathrm{GH}$ concentration in the plasma of rats fed the dietary ornithine may be effected by the ornithine itself, not mediated by the arginine. However, little information on the effect of dietary ornithine on the ghrelin concentration in the plasma and gastrointestinal tract is available for young rats. The concentration and mRNA level of ghrelin in the plasma and duodenum should be measured in the further examination of the mechanism by which the dietary addition of ornithine alters brain protein synthesis.

In the brain regions of rats in the present study, RNA activity, rather than RNA concentration, in the group fed the $20 \%$ casein + ornithine diet group was higher than in the $20 \%$ casein + arginine diet group or control group fed the $20 \%$ casein diet alone (Table 3). Correlations between the fractional rate of protein synthesis and RNA activity were significant in the cerebral cortex $(r=0.977, p<0.001)$ and cerebellum $(r=0.970$, $p<0.001)$. Hormonal treatment such as GH also appeared to elevate the rate of protein synthesis and RNA activity in the brain (10). Therefore, the higher RNA activity in rats fed the $20 \%$ casein + ornithine diet may have increased the rate of brain protein synthesis in this group.

Several studies indicated that RNA activity represented the changes in the translational phase of tissue protein synthesis (26). Little information on the mechanism by which dietary ornithine or arginine regulates RNA activity in the brain of young rats is available. In visceral organs and the brain, the stimulations of protein synthesis caused by amino acids are demonstrated to be mediated by the increase in the initiation of mRNA translation (27-30). Measurement of the initiation factors of mRNA translation in the brain should be included in further studies of the effect of the addition of ornithine or arginine to the basal diet on protein synthesis in rats.

In the present study, the fractional rates of protein synthesis and RNA activity in the liver rose in the ornithine supplementation group compared with the arginine supplementation group in rats. This observation demonstrates that the arginine itself also controls the body concentration of $\mathrm{GH}$ and increase in in vivo protein synthesis in the liver of young rats, and that the 
regulatory effect of arginine on hepatic protein synthesis is weaker than that of ornithine.

The results suggest that treatment with arginine is likely to increase the concentrations of $\mathrm{GH}$ and the rate of brain protein synthesis in rats, and that the effects of arginine on brain protein synthesis and GH concentration were lower than those of ornithine. The RNA activity is at least partly related to the fractional rate of brain protein synthesis.

\section{Acknowledgments}

The authors are grateful to $\mathrm{C}$. Takemoto and Y. Hayata for their valuable technical assistance.

\section{REFERENCES}

1) Goldspink DF, Lewis SEM, Kelly FJ. 1984. Protein synthesis during the developmental growth of the small and large intestine of the rat. Biochem J 217: 527-534.

2) Lewis SEM, Kelly FJ, Goldspink DF. 1984. Pre- and postnatal growth and protein turnover in smooth muscle, heart and slow- and fast-twitch skeletal muscles of the rat. Biochem J 217: 517-526.

3) Millward DJ, Garlick PJ, Nnanyelugo DO, Waterlow JC. 1976. The relative importance of muscle protein synthesis and breakdown in the regulation of muscle mass. Biochem J 156: 185-188.

4) Symmons RA, Maquire EJ, Rogers QR. 1972. Effect of dietary protein and feeding schedule on hepatic polysome pattern in the rat. J Nutr 102: 639-646.

5) Yokogoshi H, Sakuma Y, Yoshida A. 1980. Effect of dietary protein quality and quantity on hepatic polyribosome profiles in rats. J Nutr 110: 1347-1353.

6) Beverly JL III, Gietzen DW, Rogers QR. 1991. Protein synthesis in the prepyriform cortex: effects on intake of an amino acid-imbalanced diet by Sprague-Dawley rats. J Nutr 121: 754-761.

7) Yokogoshi H, Hayase K, Yoshida A. 1992. The quality and quantity of dietary protein affect brain protein synthesis in rats. J Nutr 122: 2210-2217.

8) Deijen JB, de Boer H, van der Veen EA. 1998. Cognitive changes during growth hormone replacement in adult men. Psychoneuroendocrinology 23: 45-55.

9) Kato H. 2002. Molecular biology of protein metabolism. In: Molecular Nutrition (Kakinuma J, ed), p 50-64. Koseikan, Tokyo.

10) Ohsumi M, Tujioka K, Hayase K, Nagata S, Yokogoshi H. 2008. The growth hormone affects the brain protein synthesis rate in hypophysectomized aged rats. J Nutr Sci Vitaminol 54: 76-81.

11) Bucci L, Hichson JF, Pivarnik JM, Wolinsky I, MaMahon JC, Turner SD. 1990. Ornithine ingestion and growth hormone release in bodybuilders. Nutr Res 10: 239-245.

12) Tujioka K, Yamada T, Aoki M, Morishita K, Hayase K, Yokogoshi H. 2012. Dietary ornithine affects the tissue protein synthesis rate in young rats. J Nutr Sci Vitaminol 58: 297-302.

13) Tujioka K, Yamada T, Abiko H, Aoki M, Morishita K, Hayase K, Yokogoshi H. 2012. Effect of dietary ornithine on the brain protein synthesis rate in hypophysectomized aged rats. J Nutr Sci Vitaminol 58: 346-353.

14) Alba-Roth J, Müler OA, Schopohl J, von Werder K. 1988.
Arginine stimulates growth hormone secretion by suppressing endogenous somatostatin secretion. J Clin Endocrinol Metab 67: 1186-1189.

15) Hayase K, Yokogoshi H. 1994. Age affects brain protein synthesis in rats. J Nutr 124: 683-688.

16) Garlick PJ, McNurlan MA, Preedy VR. 1980. A rapid and convenient technique for measuring the rate of protein synthesis in tissues by injection of $\left[{ }^{3} \mathrm{H}\right]$ phenylalanine. Biochem J 192: 719-723.

17) Reinstein DK, Isaacson RI, Dunn AJ. 1979. Regional change in 2-deoxyglucose uptake after neocortical and hippocampal destruction. Brain Res 175: 392-397.

18) Lowry OH, Rosebrough NJ, Farr AL, Randall RJ. 1951. Protein measurement with the Folin phenol reagent. J Biol Chem 193: 265-275.

19) Fleck A, Munro HN. 1962. The precision of ultraviolet absorption measurements in the Schmidt-Thannhauser procedure for nucleic acid estimation. Biochim Biophys Acta 55: 571-583.

20) Hayase K, Koie M, Yokogoshi H. 1998. The quantity of dietary protein affects brain protein synthesis rate in aged rats. J Nutr 128: 1533-1536.

21) Snedecor GW, Cochran WG. 1967. Statistical Methods, 6th ed, p 135-171. Iowa State University Press, Ames.

22) O'Kane RL, Vina JR, Simpson I, Zaragoza R, Makoshi A, Hawkins RA. 2006. Cationic amino acid transport across the blood-brain barrier is mediated exclusively by system +. Am J Physiol Endocrinol Metab 291: 412-419.

23) Ohinata K. 2013. Amino acids acting on the gastrointestinal tract-Growth hormone secretion and gut motility-. Amino Acid Research 7: 97-100 (in Japanese).

24) Kojima M, Hosoda H, Date Y, Nakazato M, Matsuo H, Kangawa K. 1999. Ghrelin is a growth-hormonereleasing acylated peptide from stomach. Nature $\mathbf{4 0 2}$ : 656-660.

25) Date Y, Murakami N, Toshinai K, Matsukura S, Niijima A, Matsuo H, Kangawa K, Nakazato M. 2002. The role of the gastric afferent vagal nerve in ghrelin-induced feeding and growth hormone secretion in rats. Gastroenterology 123: 1120-1128.

26) Jepson MM, Bates PC, Millward DJ. 1988. The role of insulin and thyroid hormones in the regulation of muscle growth and protein turnover in response to dietary protein in the rat. Br J Nutr 59: 397-415.

27) Flaim KE, Liao WSL, Peavy DE, Taylor JM, Jefferson LS. 1982. The role of amino acids in the regulation of protein synthesis in perfused liver. II. Effects of amino acid deficiency of peptide chain initiation, polysomal aggregation, and distribution of albumin mRNA. J Biol Chem 257: 2939-2946.

28) Anthony JC, Yoshizawa F, Gautsch Anthony T, Vary TC, Jefferson LS, Kimball SR. 2000. Leucine stimulates translation in skeletal muscle of postabsorptive rats via a rapamycin-sensitive pathway. J Nutr 130: 2413-2419.

29) Kimball SR, Jurasinski CV, Lawrence JC, Jefferson LS. 1997. Insulin stimulates protein synthesis in skeletal muscle by enhancing the association of eIF-4E and eIF4G. Am J Physiol 272: C754-759.

30) Ohsumi M, Yoshizawa F, Hayase K, Yokogoshi H. 2010. Effect of quality and quantity of dietary protein on 4E-BP1 and S6K1 phosphorylation of brains in aged rats. J Nutr Sci Vitaminol 56: 319-325. 